\title{
A Revision of the Genus Sanyuania Zhao and Han, 1980 Ostracoda, Crustacea) with the Description of New Species from the Late Cainozoic of China
}

\author{
QUANHONG ZHAO \\ Department of Marine Geology \\ Tongii University \\ Shanghai 200092 \\ China
}

\author{
ROBIN WHATLEY \\ $\overline{\text { Micropalaeontology Research Group, }}$ \\ Institute of Earth Studies, \\ University College of Wales, \\ Aberystwyth, SY23 3DB, UK
}

\begin{abstract}
The endemic genus Sanyuania, one of the most important elements of the Cainozoic brackish water faunas unique to China, is redescribed, and 3 new species, S. wangi, S. cuneata and S. sublaevis are established, based on Quaternary material from the eastern coast of China. The evolution of the genus is discussed and a general trend involving a reduction in the strength of carapace ornamentation with time is established, as is a general migration seawards exhibited by subsequent chronological species. J. Micropalaeontol., 11 (2): 151-158, December 1992.
\end{abstract}

\section{INTRODUCTION}

Sanyuania was first recorded in manuscript by Huang in 1970 's from the Pliocene and early Pleistocene of the Fenwei Basin of Shanxi Province, central China. It has subsequently proved to be widespread in Quaternary sediments of eastern China, along the coasts of the Yellow and East China Seas (Zhao and Han, 1980; Zhao et al., 1986; Hou et al., 1982; Wang, 1982; Zhang, 1985; Yang et al., 1988; and others). The significance of this genus in the paleoenvironmental analysis of these sediments has been briefly mentioned by one of us (Zhao and Han, 1980; Zhao et al., 1986) and its appearance in Quaternary sediments of coastal areas is considered as a reliable indicator of marine-continental transitional facies. Sanyuania was once thought to be monotypic. Additional material, however, have been collected in recent years during our studies of the late Cainozoic and Recent Ostracoda of eastern China. The purpose of this paper is to describe these new species of Sanyuania and to emend its diagnosis, and also to comment on its significance as one of the most important elements of late Cainozoic brackish water faunas of China.

All type and figured specimens described herein are housed in the Department of Palaeontology, British Museum of Natural History.

\section{SYSTEMATIC DESCRIPTIONS \\ Order Podocopida Sars, 1866 \\ Suborder Podocopina Sars, 1866 \\ Superfamily Cytheracea Baird, 1850 \\ Family CythereididaeE Sars, 1925 \\ Genus Sanyuania Zhao \& Han, 1980 \\ (= Gamagyangnella Choe, 1988)}

Emended diagnosis. Small; laterally compressed in dorsal view with slightly pointed ends; subovate to subtriangular in lateral view. Sexually dimorphic; female slightly higher than male. Anterior margin broadly rounded, posterior margin narrowly rounded to bluntly pointed, dorsal margin straight, ventral margin with slight oral concavity. Greatest height at anterior cardinal angle, greatest length well below mid-height; ornament ranging from reticulate with posteroventral tubercle to reticulo-costate with punta, to punctate or smooth. Valves subequal along margins but RV slightly overhangs LV along most of dorsal margin except at posterior cardinal angle where LV overlaps RV. Eye spot incospicuous. Normal pore canals sieve type. Inner lamella of medium width, with vestibula at each end; radial pore canals short, simple, few. Hinge highly modified merodont in which the terminal elements alternate in a manner unique among the Ostracoda. In the left valve the anterior terminal element is a positive dentate bar while the posterior terminal element is a negative loculate groove; these elements are connected by a smooth or faintly denticulate bar; right valve hinge complementary. In one species the anterior element of the left valve is smooth. Adductor scars in oblique row of four, frontal scar U-shaped. Type species. Sanyuania psaronius Zhao \& Han, 1980

Distribution. Pliocene and early Pleistocene, central China; Quaternary and Recent, eastern China; Recent, Korea.

Remarks. Sanyuania was recognized and systematically described in manuscript by Huang more than 25 years ago and remained unpublished until 1980. The generic and specific names Sanyuania psaronius were applied by Zhao and Han in 1980 but attributed to Huang, thus creating nomina nuda. However, the description of the genus and its type species by Huang (in Lin et al., 1982) served to validate these nomina nuda but, unfortunately this results in the genus and its type species being unascribable to Huang. The authors of Sanyuania and of S. psaronius are by default, therefore, Zhao and Han, 1980. The hinge of this genus was referred to by Huang (in Lin et al., 1982) as amphidont, but our SEM illustrations in Pl. 1 clearly show it to be of highly modified merodont type.

Gamagyangnella Choe, 1988 despite the fact that the anterior 
terminal element of its hinge was described as smooth, is clearly a junior synonym of Sanyuania.

\section{Sanyuania psaronius Zhao and Han}

(Pl.1, figs.1-9)

1980 Sanyuania psaronius Huang. Zhao and Han, Pl.1, fig.

1982 Sanyuania psaronius Huang, in Lin et al., p.87, Pl.8,figs. 34-37

1983 Gen et sp.1, Hou et al.,p.245, pl.87, figs.17-19.

1985 Sanyuania psaronius Huang, Zhao et al., Pl.1, fig.10

Diagnosis. A reticulate species of Sanyuania with a prominent, punctate posteroventral tubercle.

Material. More than 300 specimens. Figured specimens are all from Pleistocene core samples, Hole SX3, Changzhou, Jiangsu, Province, China.

Distribution. Pliocene -early Pleistocene of the Fenwei Basin, central China, co-occurring with such brackish-water ostracods as Callistocythere trokis Huang, Cyprideis torosa (Jones), Tanella liquensis Huang and the foraminifera Ammonia tepida, Discorbis sp. (Lin et al., 1982). In the Pleistocene and Holocene of coastal areas of eastern China, coexisting with euryhaline marine ostracods dominated by Sinocytheridea impressa (Brady), Tanella opima Chen and Spinileberis furuyaensis Ishizaki and Kato, and foraminifera dominated by Ammonia beccarii vars. and Protelphidium glabrum (Zhao and Han, 1980; Zhao et al., 1986) (Fig.1).

Emended description. Subtriangular, posterior margin slightly truncated above and narrowly rounded below. Surface reticulation with multiangular fossae and delicately punctate solae. A small but prominent, punctate, rounded tubercle developed posteroventrally. Sieve-type normal pore canals rounded and small. Inner lamella moderately wide with narrow vestibulae anteriorly and posteriorly.

Some 12 radial pore canals anteriorly and 8 posteriorly. Adductor scars in an oblique row.. Hinge of LV with a bar anteriorly bearing 3 large teeth; posteriorly the terminal element is a quadriloculate socket; median element a smooth bar with weak denticles anteriorly and posteriorly.

$\begin{array}{lccc}\text { Dimensions (mm) } & \text { length } & \text { height } & \text { width } \\ \text { RV female OS13723 } & 0.34 & 021 & \\ \text { LV male OS13724 } & 0.31 & 0.17 & \\ \text { LV female OS13725 } & 0.34 & 0.20 & \\ \text { LV female OS 13726 } & 0.33 & 0.20 & \\ \text { LV female OS13727 } & 0.33 & 0.20 & \\ \text { Car. female OS13728 } & 0.32 & 0.21 & 0.24\end{array}$

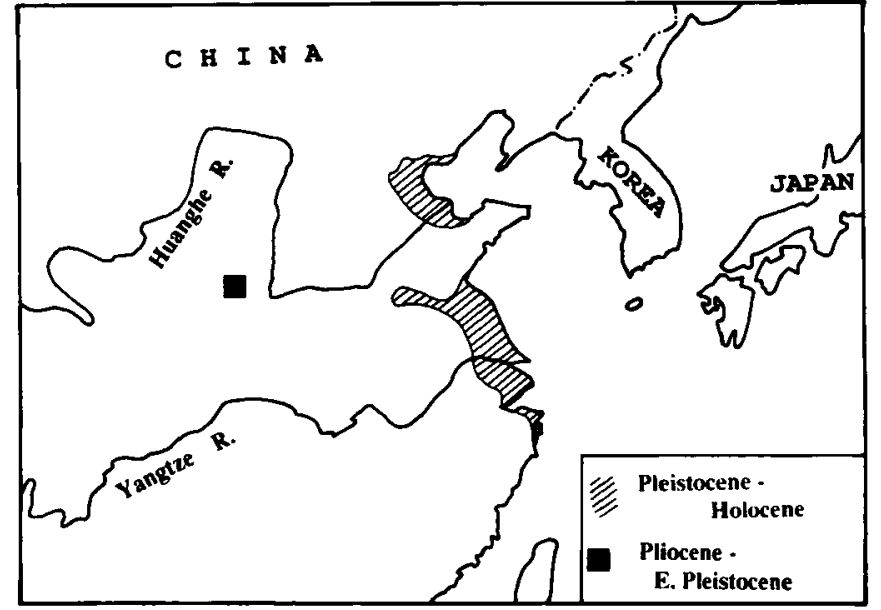

Fig. 1. Distribution of Sanyuania psaronius in China.

Remarks. Comparing the specimens figured in this paper with those from the type locality, near tyhe city of Sanyuan, in the south of Shanxi Province, central China, which were kindly sent by Mrs. Huang who first encountered this species in the 1970's, the authors found they are certainly conspecific. S. psaronius is readily distinguishable from all other species due to its reticulate surface and posteroventral tubercle.

\section{Sanyuania wangi sp.nov. (Pl.1, figs. )}

Derivation of name. Named in honour of Wang Qiang, Tianjin Institute of Geology \& Mineral resouces, for his contribution to our understanding of the Quaternary Ostracoda of China and his kindness in providing the specimens.

Diagnosis. Sanyuania characterized by its surface ornament of pucta and concentric ridges.

Holotype. Right valve, female (OS13729), from Xuzhou, Jiangsu Province, approx. lat. $34^{\circ} 17^{\prime} \mathrm{N}$, long. $117^{\circ} 17^{\prime} \mathrm{E}$, mid-Pleistocene, brown silty clay.

Paratypes. Nos. OS 13730-32 are all from Pleistocene core samples, Tianjiang.

Material. More than 20 specimens.

Distribution. Pleistocene and Holocene, coastal plain of eastern China (Fig.2). It always occurs with the twoeuryhaline marine ostracods Sinocytheridea impressa, Leptocythere ventriclivosa Chen and non-marine ostracods such as Candona spp. and Candoniella spp.. The present species seems to be extinct but in the past to have lived in inland brackish water or supratidal environments of low salinity.

Description. Surface ornamented with weak concentric ribs and intercostal punctae which tend to merge into reticulation

Figs. 1-9. Sanyuania psaronius Zhao and Han.

Fig. 1, RV, female (OS13723), ext. lat., X 135; Fig. 2, RV, male (OS13724), ext. lat. X 130; Fig. 3, LV, female (OS13725), ext. lat. X 135; Fig. 4, LV, female (OS13726), int. lat. X 135; Fig. 5, RV, female (OS13727), int. lat. X 135; Fig. 6, detail of reticulation and sieve type normal canal pore, (OS13725); ext. lat. X 780; Fig. 7, detail of LV hinge, (OS13726), X 345; Fig. 8, detail of RV hinge, (OS13727), X 345; Fig. 9, car. female (OS13728), dors. lat. X 145. All are from the mid-Pleistocene of Changzhou, Jiangsu Province. 


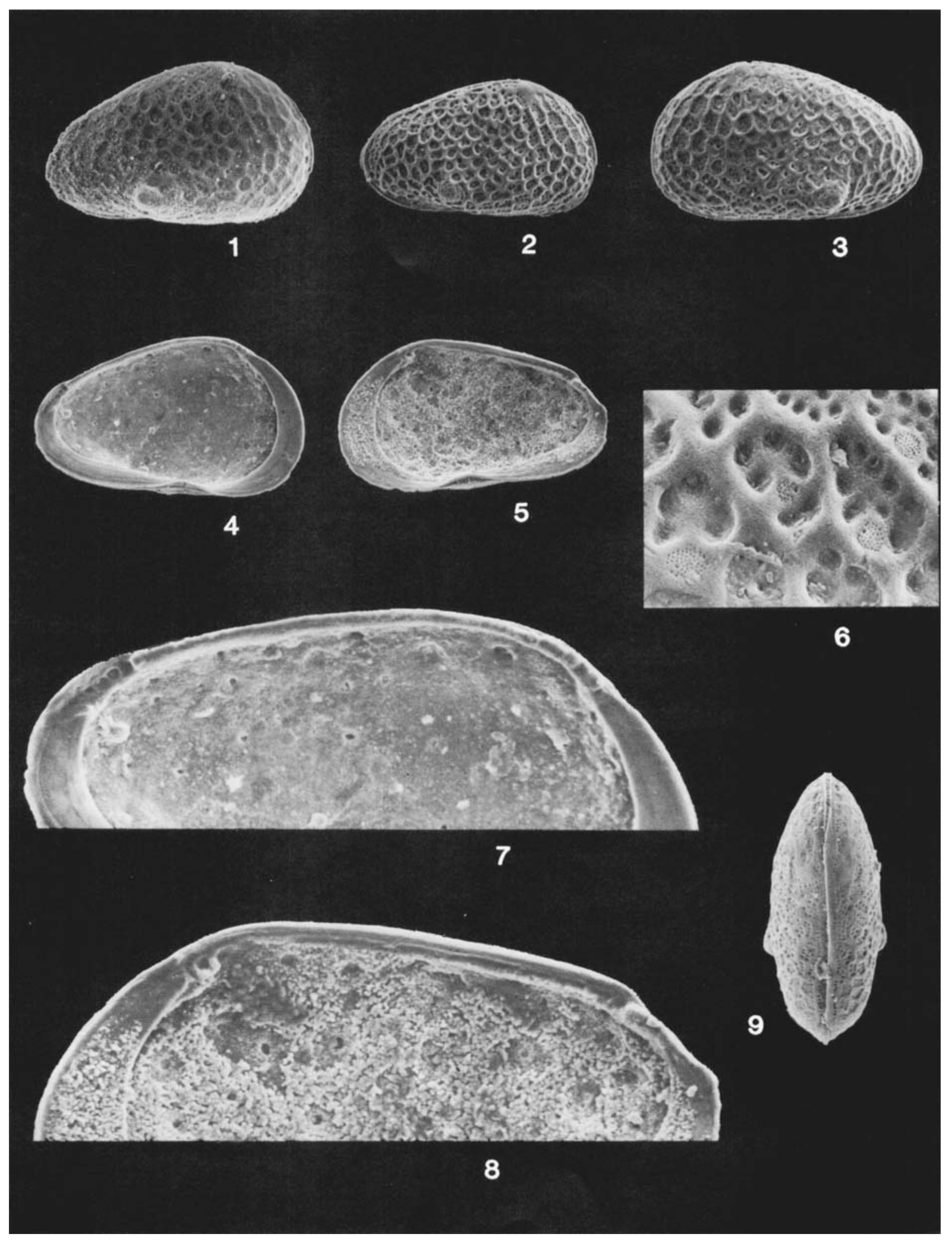




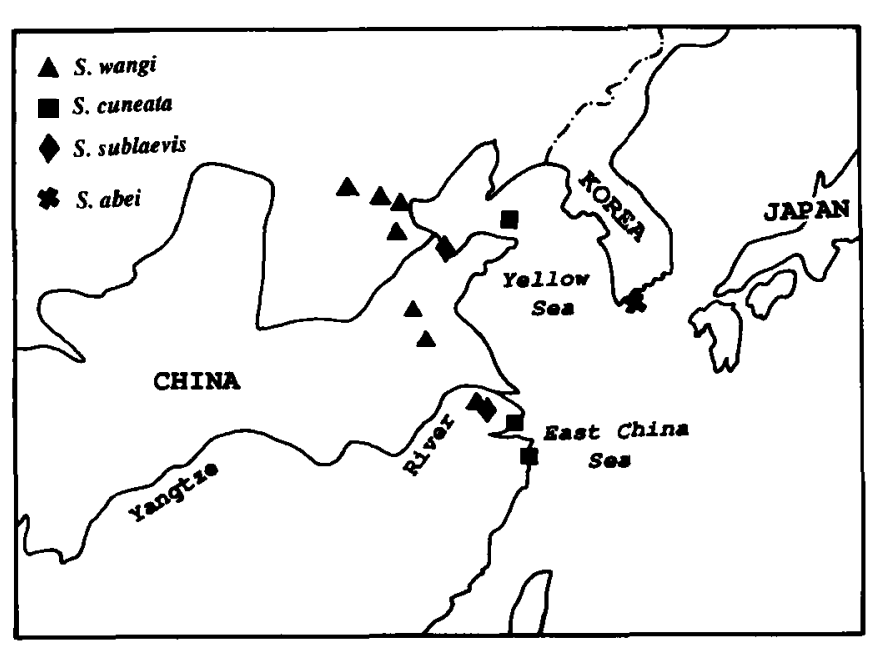

Fig. 2. Distribution of Sanyuania wangi, S. cuneata and S. sublaevis in China

centrally. All other characters as for genus except that the anterior socket of the RV has a delicate anti-slip bar ventrally.

$\begin{array}{lccc}\text { Dimensions (mm) } & \text { length } & \text { Height } & \text { Width } \\ \text { Holotype RV female OS13729 } & 0.30 & 0.19 & \\ \text { Paratype car. male OS13730 } & 0.30 & 0.17 & 0.13 \\ \text { Paratype RV female OS13731 } & 0.30 & 0.19 & \\ \text { Paratype Car. male OS13732 } & 0.28 & 0.17 & 0.11\end{array}$

Remarks. This species is most similar in lateral outline and internal features to $S$. psaronius, but differs in its costate and punctate surface and in lacking a posteroventral node.

\section{Sanyuania cuneata sp. nov.}

$$
\text { (Pl.1, figs. 4-6) }
$$

Derivation of name. Latin. cuneatus = cuneate, wedge-shaped, with reference to the cuneate outline in lateral view.

Diagnosis: A species of Sanyuania characterized by its cuneate outline in lateral view, punctate surface ornament and compressed posterior margin.

Holotype. Carapace, male (OS13733), from a supratidal pool, off Xiangshangang Bay, Zhejiang Province, approx. lat. $29^{\circ}$ $30^{\prime} \mathrm{N}$, long. $121^{\circ} 25^{\prime} \mathrm{E}$, Recent, grey silt.

Paratypes. Nos.OS13734-5. All from shelf core samples, northern part of the Yellow Sea, late Pleistocene, clay.
Material. Seven specimens.

Distribution. Late Pleistocene and Recent, eastern China. Fossil specimens are from shelf core samples of the northern Yellow Sea, and Recent specimens from a supratidal pool with $17 \mathrm{o} / \mathrm{oo}$ salinity, Zhejiang Province (Fig.2).

Description. Elongate and cuneate in lateral view with sub-caudate posterior with posterodorsal slope truncated. Surface ornament of punctae which are sub-concentrically disposed and which decrease in size peripherally. The junction between the lateral and ventral surface is slightly sub-alate. Carapace markedly compressed along posteroventral and posterior margins.Other characters as for genus.

$\begin{array}{lccc}\text { Dimensions (mm) } & \text { length } & \text { Height } & \text { Width } \\ \text { Holotype Car. male OS13733 } & 0.30 & 0.15 & 0.10 \\ \text { Paratype car. male OS13734 } & 0.32 & 0.17 & \\ \text { Paratype RV female OS13735 } & 0.31 & 0.15 & \end{array}$

Remarks. By virtue of its elongate cuneate outline, punctate surface, compressed posterior margin and sub-alar structure, the present species differs from all other species of the genus.

\section{Sanyuania sublaevis sp.nov} (Pl. 2 , figs. 8-14)

Derivation of name. Latin. Laevis = smooth, with reference to the nearly smooth surface of this species.

Diagnosis. Surface nearly smooth with very feeble ribs on end margins; normal pore canals large and very evident.

Holotype. Right valve, female (OS13736), from Jianghu County, Jiangsu Province, approx. lat. $3225^{\prime} \mathrm{N}$, long. $11950^{\prime} \mathrm{E}$, Holocene, clay; co-occurring with a rich ostracod fauna dominated by Cocoonocythere sinensis Zhao and Foraminifera dominated by Ammonia beccarii vars.

Partypes. Nos. OS13738-41; OS13737 was collected from the mouth of the Xiaoqinghe River, Recent; all others are from the type locality.

Material. More than 50 specimens.

Distribution. Holocene and Recent, eastern China. Living specimens were found in the estuary of a small river, the Xiaoqinghe River, Shandong Province, which flows into the Bohai Gulf, in a salinity of $0.5-1.3 \%$ (Fan, 1988, pers. comm.). Fossil specimens have been found from the coastal plain off the southern Yellow and the northern East China Seas, co-occurring with euryhaline ostracods and Foraminifera

Figs. 1-3, 7. Sanyuania wangi sp. nov.

\section{Explanation of Plate 2}

Fig. 1, Holotype, RV, female (OS13729), mid-Pleistocene, Xuzhou, Jiangsu Province, ext. lat. X 153; Fig. 2, paratype, car. male (OS13730), LV lat. X 153; Fig. 3, paratype, RV, female (OS13731), int. lat. X 153; Fig. 7, paratype, car. male (OS13732), dors. lat. X 175; Figs. 2, 3 and 7, Pleistocene, Tianjin.

Figs. 4-6. Sanyuania cuneata sp. nov.

Fig. 4, paratye, RV, female (OS13734), Late Pleistocene, the Yellow Sea, ext. lat. X 144; Fig. 5, Holotype, car. male (OS13733), Recent, Xiangshangang Bay, Zhejiang Province, LV lat. X 153; Fig. 6, paratype, RV, male (OS13735), Late Pleistocene, the Yellow Sea, int. lat. X 142; Figs. 8-14. Sanyuania sublaevis sp. nov.

Fig. 8, paratype, car., female (OS13737), dors. lat. X 132; Fig. 9, paratype, LV, male (OS13738), ext. lat. X 132; Fig. 10, holotype, RV, female (OS13736), int. lat. X 132; Fig. 11, detail of RV hinge (OS13736), X 305; Fig. 12, paratype, RV, female (OS13739), ext. lat. X 132; Fig. 13, paratype, RV, male (OS13740), ext. lat. X 145; Fig. 14, paratype, LV, female (OS13741), int. lat. X 132. Fig.8, Recent, Xiaoqinghe River mouth; Figs.9-14, Holocene, Jianhu County, Jiangsu Province. 

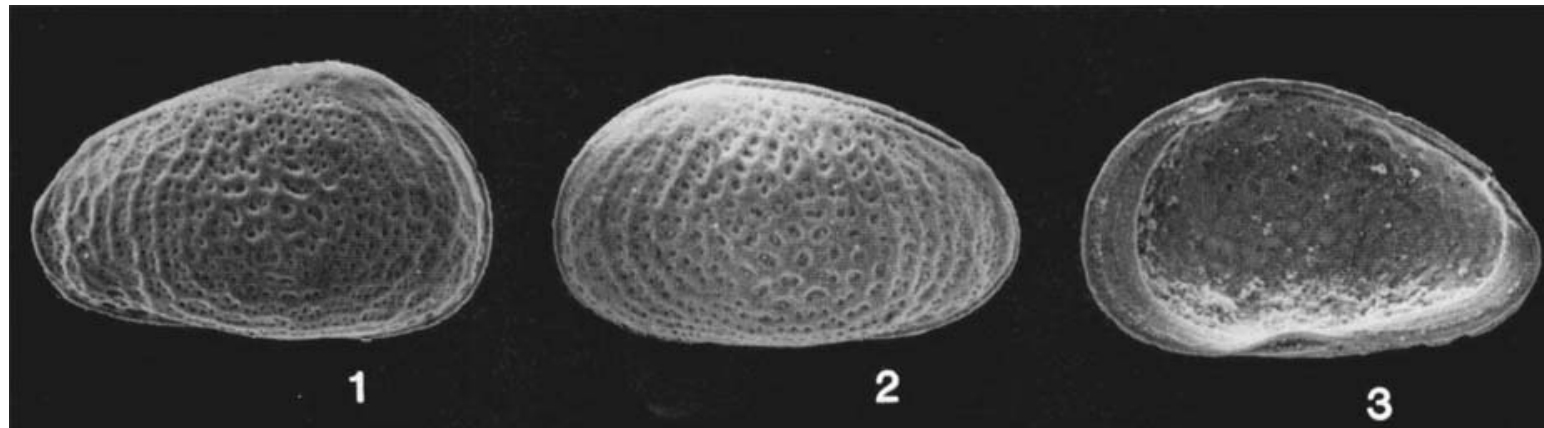

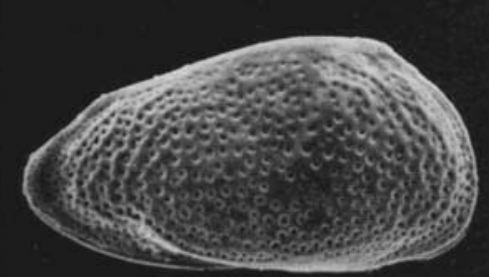

4

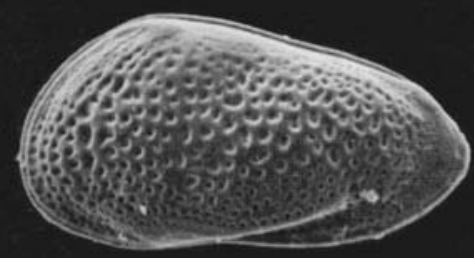

5
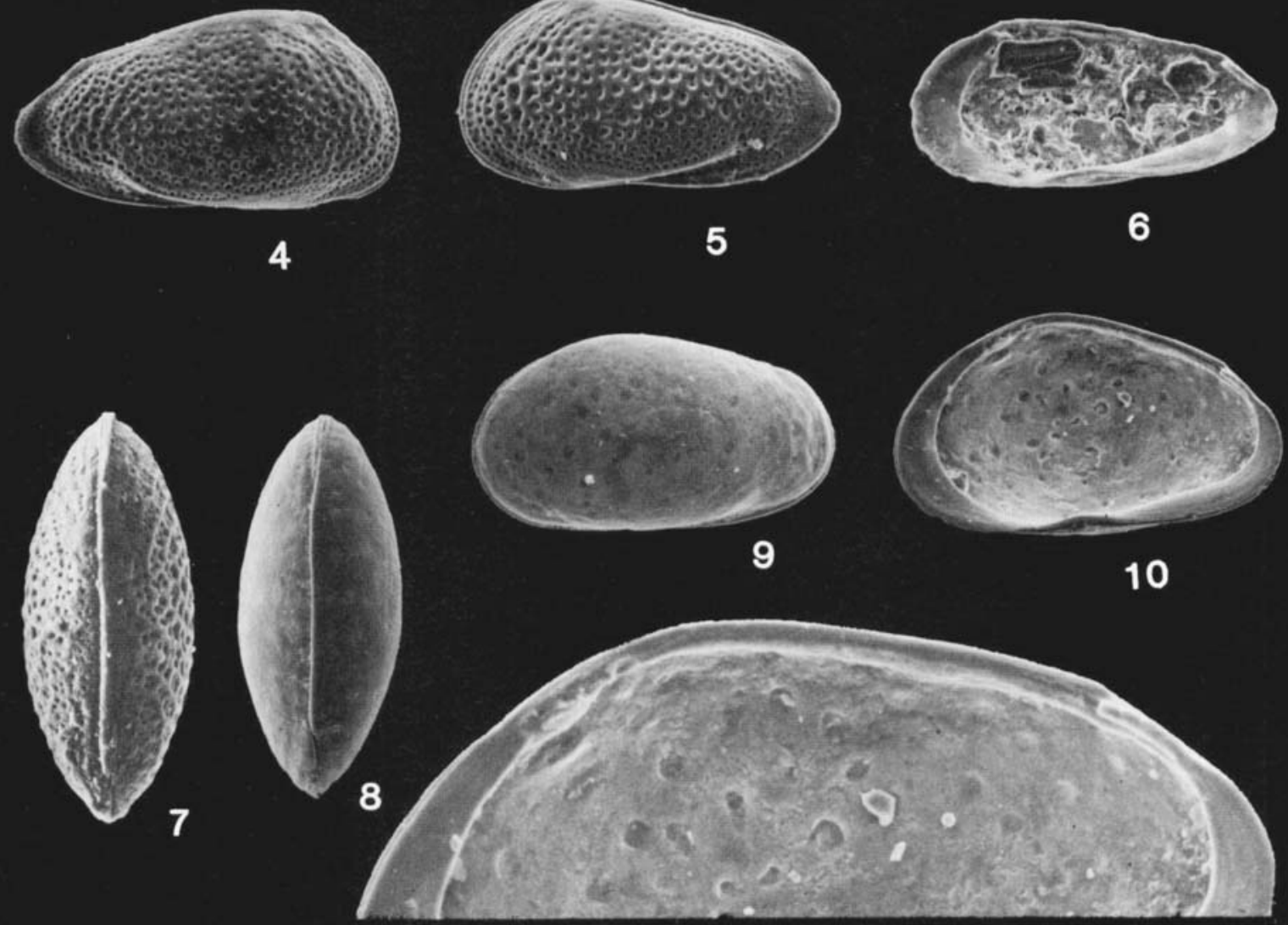

11

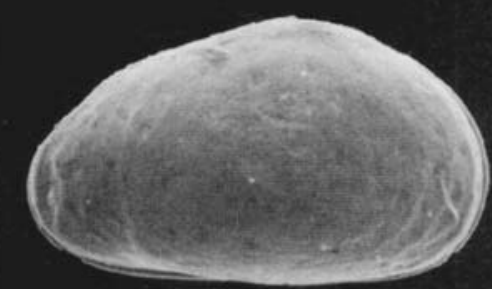

12

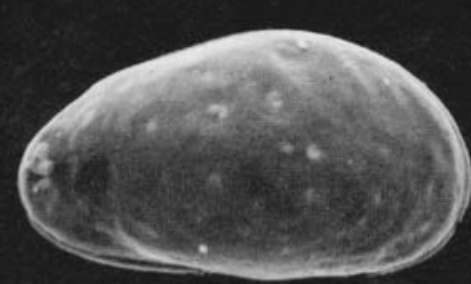

13

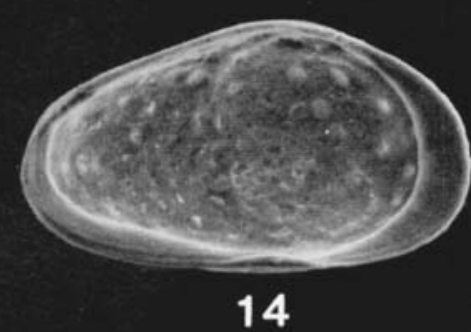




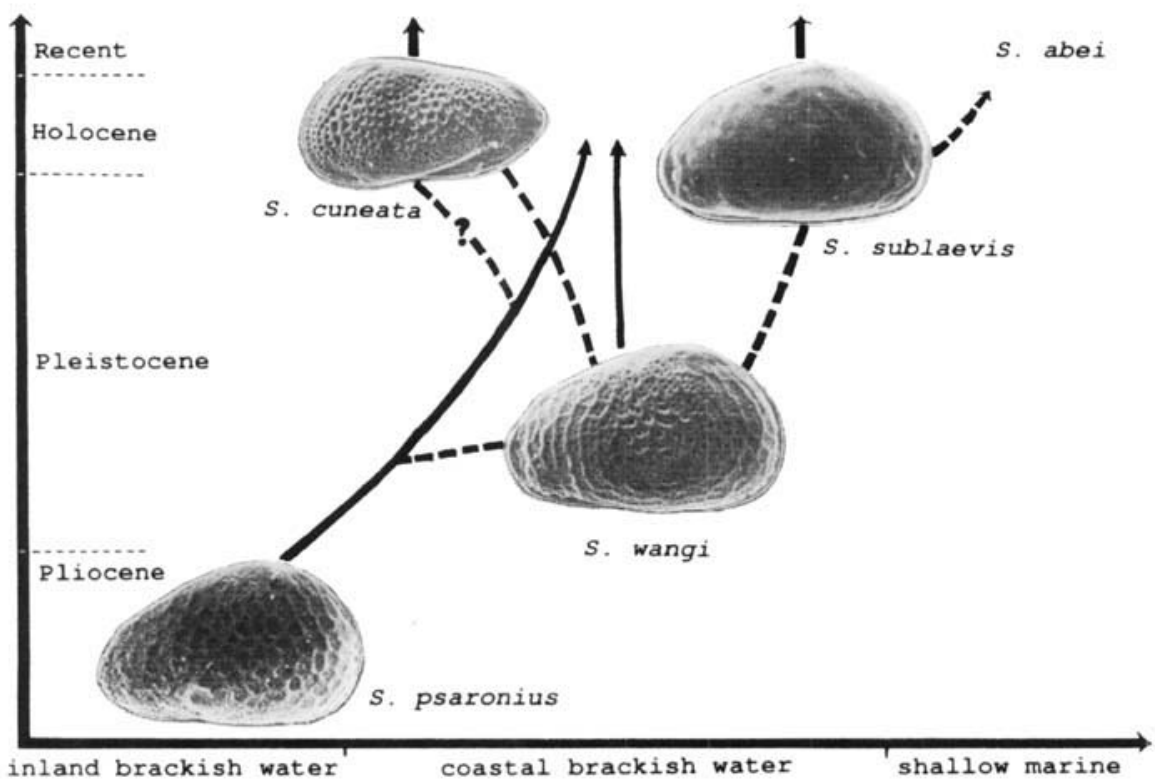

Fig. 3. Possible evolutionary relationships within Sayunia.

such as Cocoonocythere sinensis Zhao, Sinocytheridea impressa (Brady), Spinileberis pulchra Chen and Ammobia beccarii vars., Protelphidium glabrum (Fig.2).

Description. Cardinal angles distinct in RV. Surface nearly smooth centrally but with a few feeble ribs anteriorly and posteriorly. Sieve-shaped normal pore canals large, rounded and very evident. Carapace in dorsal view with gently arched lateral margins and acutely pointed ends; greatest width centrally. Inner lamella moderately wide with relatively large terminal vestibulae; radial pore canals short, straight and simple, 10-12 anteriorly and 8-9 posteriorly. Other characters as for genus.

$\begin{array}{lccc}\text { Dimensions (mm) } & \text { length } & \text { Height } & \text { Width } \\ \text { Holotype RV female OS13736 } & 0.35 & 0.21 & \\ \text { Paratype car. female OS13737 } & 0.34 & 0.19 & 0.15 \\ \text { Paratype LV male OS13738 } & 0.32 & 0.17 & \\ \text { Paratype RV female OS13739 } & 0.35 & 0.22 & \\ \text { Paratype RV male OS13740 } & 0.32 & 0.18 & \\ \text { Paratype LV female OS13741 } & 0.35 & 0.20 & \end{array}$

Remarks. This species is characterized by its virtually smooth surface, which is shares with Sanyuania abei (Choe), 1988. The two species differ, however, in that the latter is more elongate and more pointed posteriorly.

\section{DISCUSSION}

Sanyuania is found only in the Pliocene to Recent central and eastern China and southern Korea. Of the five species reported above, $S$. psaronius is the oldest and the only one from the Pliocene-early Pleistocene. The first appearance of $S$. wang $i$ is dated as early to mid-Pleistocene; and that of $S$. cuneata and S. sublaevis is late Pleistocene. S. abei is known only from the Recent. S. psaronius has a wide distribution from the central inland basin to the eastern coastal areas, while the other 3 Chinese species are limited to the eastern coastal areas. $S$. $a b e i$ is apparently confined to Recent shallow seas off the southern coast of Korea.

It is probable that $S$. psaronius is the ancestral species of the genus, although relationships to an ancestral genus are unknown. The probable speciation patterns within the Sanyuania lineage is shown in Fig.3: S. wangi evolved from S. psaronius in the early Pleistocene, and subsequently in the late Pleistocene, S. cuneata and $S$. sublaevis evolved from either $S$. wangi or S. psaronius. The former is more likely given the observed similarity in ornament between these species. S. abei was almost certainly derived from $S$. sublaevis, probably late in geological time. The evolutionary sequence S. psaronius S. wangi - S. cuneata - S. sublaevis - S. abei illustrated in Fig. 3, is also a morphological series illustrating a general reduction in strength of ornament with time from the robustly reticulate/ punctate S. psaronius to the completely smooth S. abei.

During the Pliocene - Recent evolution of this genus, a trend of seaward mirgration through time takes place. In the Pliocene and early Pleistocene, S. psaronius occurred only in the inland brackish water basin of central China (Lin et al., 1982), but since the mid-Pleistocene all 4 Chinese species have been restricted to the coastal areas of eastern China where they have become one of the most common inhabitants of marginal marine environments, such as estuaries, lagoons and tidal marshes (Zhao \& Han, 1980; Zhao et al., 1986). The Recent Korean species, S. abei, has become a typical marine form living in shallow seas with a depth range from 21.5 to $75 \mathrm{~m}$ (Choe, 1988). S. abei is probably confined to the shallow

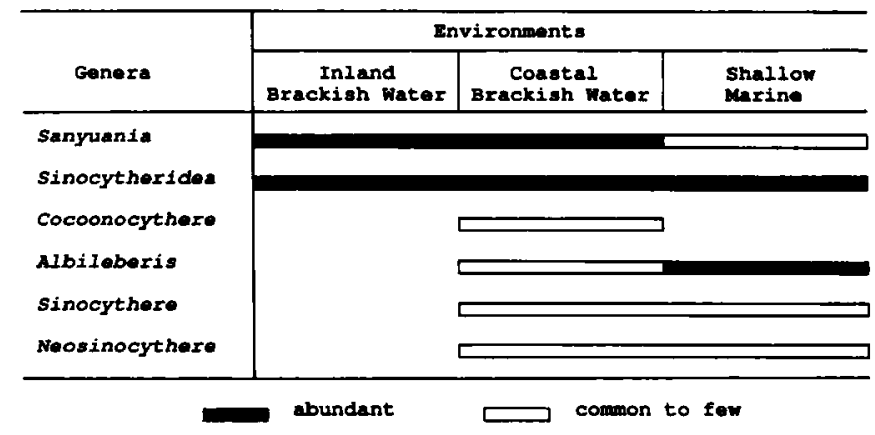

Fig. 4. Ecological distribution of characteristic genera of late Cainozoic brackish water ostracod faunas of central and eastern China.

water part of this range and those specimens found by Choe at greater depths were post-mortem transported seawards.

The late Cainozoic brackish water ostracod faunas of east- 


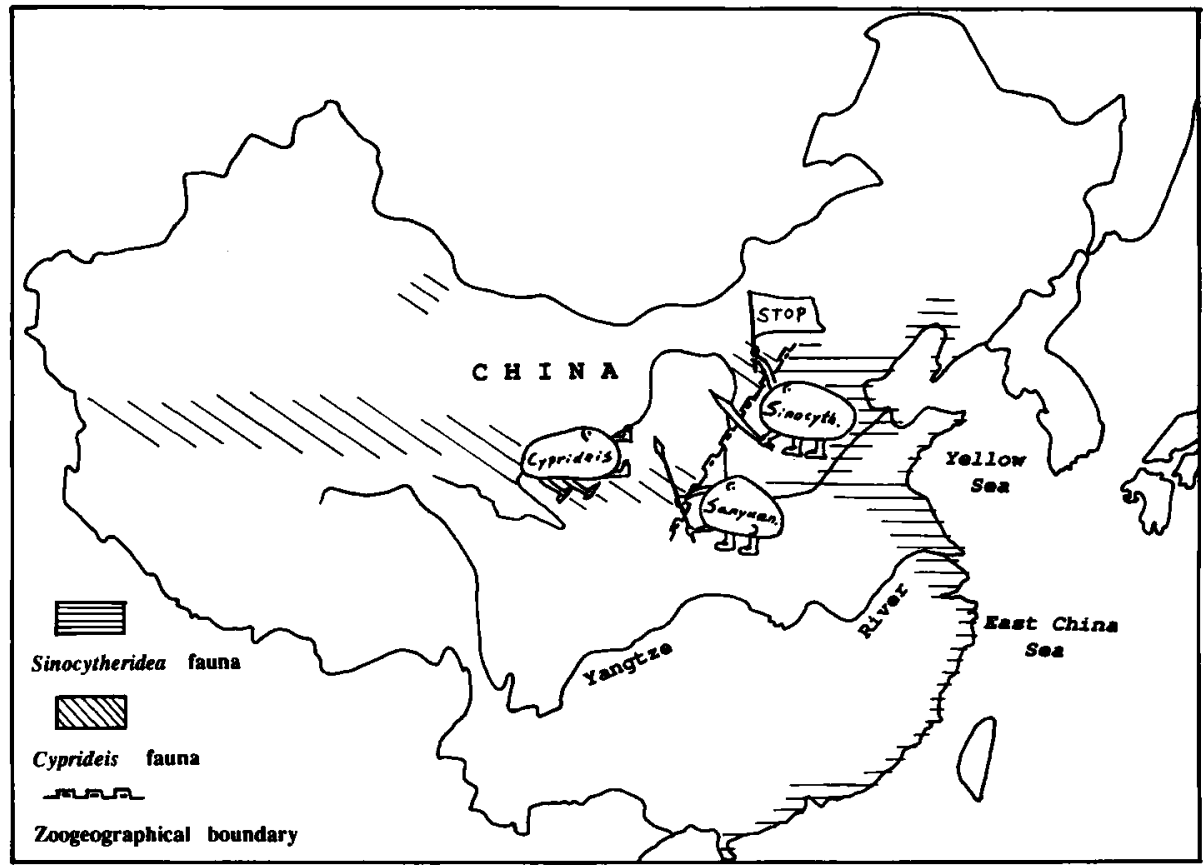

Fig. 5. Distributionary area of two types of late Cainozoic brackish water ostracod faunas and approximate boundary between them. To the west is the Cyprideis type and to the east the Sinocytheridea type.

ern China are characterized by Albileberis, Cocoonocythere, Sinocythere, Sanyuania, Sinocytheridea and Neosinocythere. These genera occur either only in China (the former 3) or mainly in China (the latter 3) (Zhao and Wang, 1988; Zhao and Whatley,1989; Ishizaki, 1990). The ecological distribution of these genera is summarized in Fig. 4. Sinocytheridea is the most typical member of the fauna being the most widespread ecologically and geographically, and is abundant and ubiquitous in late Cainozoic brackish water faunas (Zhao and Han, 1980; Zhao et al., 1986; Zhao, 1985; Zhaoand Wang, 1988; Li, 1985; Wang et al., 1988; and others). Sanyuania is one of the important elements of brackish water faunas especially in the Pliocene and early Pleistocene of central China where it often is the dominant genus. Compared with other regions of the world, the brackish water faunas of eastern China are unique. The most notable features is the absence of the worldwide euryhaline genus Cyprideis (Jones) from both fossil and modern brackish water faunas in eastern China. Cyprideis has only been found in western and central China where it occurs in brackish formations of Miocene to Holocene age and in modern salt lakes (Yang, 1981, 1988; Lin et al., 1982; Hao and Zhen, 1984; $\mathrm{Xi}$ et al.,). The Chinese late Cainozoic brackish water ostracod faunas, therefore, can be divided into two types: the western type characterized by the presence of Cyprideis, and the eastern type where Cyprideis is replaced by Sinocytheridea and other Chinese endemic genera. The boundary between the two types is located at the central part of China (Fig.5). The absence of the otherwise ubiquitous euryhaline genus Cyprideis from both fossil and Recent faunas of eastern China has been noted by Wang et al. (1985); Zhao and Wang (1988). They argued that mutual exclusion was caused by the similar ecological requirements of $C y p r i d e i s$ and its Chinese endemic competitors.

\section{ACKNOWLEDGEMENTS}

The authors wish to express their thanks to Fan Fangxian, Huang Yuqing, Lin Hemao and Wang Quing who kindly provided specimens and useful data. Caroline Maybury and Alicia Moguilevsky and an anonymous referee made many helpful suggestions. This study was supported by the British Council ALCS and a grant from the National Nature Science Foundation of China.

Manuscript received November 1991 Manuscript accepted July 1992

\section{REFERENCES}

Choe, K., 1988. On ostracod biofacies and five new genera in Korean Seas. In Hanai, $T$. et al., (Eds), Evolutionary Biology of Ostracoda, its fundamentals and applications. Proc. 9th Int. Symposium on Ostracoda, Shizuoka, Japan, 1985. Elsevier, $121-133$.

Hanai, T., Ikeya, N. and Yajima, M., 1980. Checklist of Ostracoda from South Asia. Univ. Mus. Univ. Tokyo, Bull. 17, 1-236.

Hao, Y. and Zhen, X., 1984. On the evolution of the west Tarim gulf from Mesozoic to Cenozoic in terms of characteristics of foraminiferal faunas. Acta Micropaleont. Sinica, 1(1), 1-16. (in Chinese with English abstract)

Hou, Y. et al., 1982. Cretaceous-Quaternary Ostracode Fauna from Jiangsu. Geol. Publ. House, Beijing, 1-386. (in Chinese with English abstract).

Huang, B., 1960. Ostracod s from Gansen District, Chaidan Basin. Actn Paleont. Sinica, 12(2), 256-270. (in Chinese with English abstract).

Ishizaki, K., 1990. A setback for the genus Sinocytheridea in the Japanese mid-Pleistocene and its implications for a vicariance event. In Whatley, R. and Maybury, C. (Eds), Ostracoda and Global Events. Chapman and Hall, 139-152.

Li, S. 1985. Distribution of the ostracod thanatocoences in the Pearl River mouth area.Tropic Oceanology, 4 (4), 43-52 (in Chinese with English abstract).

Lin, H., Yuan, F. and Huang, Y., 1982. Cainozoic Ostracoda of Fenwei Basin. Contr. Petr. Geol.-Strat. Paleont., 4, 59-91. (in Chinese).

Wang, P. et al., 1988. Foraminifera and Ostracoda in Bottom Sediments of the East China Sea. Ocean Press, Beijing, 1-438. (in Chinese with English abstract).

Wang, Q., 1982. The ostracod fauna of marine and terrestrial transitional facies in western coast of the Bohai Gulf (North China) and palaeogeography during Quaternary. Marine Geol. Res., 2 (3), 36-46. (in Chinese with English abstract).

Wang, Q., Li, F., Li, Y. and Gao, X., 1987. Discussion on the naming of Quaternary transgressions in west-southern coastal plain of Bohai Sea. Acta Ocean. Sinica, 8(1), 72-82.

Wang, Q. and Wang, J. 1982. Sinocytheridea in Shanxi, China. Journ. Stratigr., 6 (3), 234-236. (In Chinese with English abstract).

Xi, Y., Wang, Q. and Gao, X., 1987. The micropaleontological fauna and stratigraphical division of a drilling hole in Shuixipu, Yuxian County, Hebei Province. Marine Geol. E Quatern. Geol., 7 (3), 91 99. (in Chinese with English abstract) 
Yang, F., 1981. Subdivision and correlation of Quaternary strata in eastern Qaidam Basin by using Ostracoda as paleoclimatological indicators. Selected Papers 1st conv. Micropal. Soc. China. 46-53. (in Chinese)

Yang, F., 1988. Distribution of the brackish-salt water ostracods in northwestern Qinghai Plateau and its geological significance. In Hanai, T. et al., (Eds), Evolutionary Biology of Ostracoda, its Fundamentals and Applications. Proc. 9th Int. Symposium on Ostracoda, Shizuoka, Japan, 1985. Elsevier, 519-530.

Zhang, H., 1985. Some new ostracodes from the Epi-Pleistocene of the western coast, Bohai Gulf. Acta Micropaleont. Sinica, 2(4), 361-367. (in Chinese with English abstract).

Zhao, Q., 1985. A study on distribution of Recent coastal ostracod faunas of the East China Sea and the Yellow Sea. Acta Ocean. Sinica, 7 (2), 193-204. (in Chinese with English abstract).
Zhao, Q. and Han, D., 1980. Late Quaternary brackish-water ostracod faunas from the area to the west of Weishanhu Lake, Jiangsu and their significance. In Wang, P. (Ed), Papers on Marine Micropaleontology. Ocean Press, Beijing, 120-129. (in Chinese with English abstract).

Zhao, Q., Han, D. and Ouyang, J., 1986. Paleoecological analysis of the Quaternary ostracods of Jiangsu. Journ. Stratigr., 10 (2), 79-87. (in Chinese).

Zhao, Q. and Wang, P., 1988. Distribution of modern ostracods in the shelf seas off China. In Hanai, T. et al., (Eds) Evolutionary Biology of Ostracoda, its Fundamentals and Applications. Proc. 9th Int.Syposium on Ostracoda, Shizuoka, Japan, 1985. Elsevier, 805-821.

Zhao, Q. and Whatley, R., 1989. Recent podocopid Ostracoda of the Sedili River and Jason Bay, southeastern Malay Penisula. Micropaleont., 35(2), 168-187. 